\title{
COMPARATIVE AND TAXONOMIC STUDIES ON FOUR Trifolium SPECIES IN EGYPT
}

(Received:7.4.2013)

\author{
By \\ H. S. Abd - El Maksoud and Zeinab M. Abd El-Naby* \\ Flora and Phyto-taxonomy Researches Department, Horticulture Research Institute. \\ *Forage Crops Research Department, Field Crops Research Institute, \\ Agriculture Research Center,Giza, Egypt.
}

\begin{abstract}
The study was conducted on three wild species found in the north coast (Porg El Arab) area in Egypt and belong to the genus ((Trifolium). The wild species are: T.esupinatum, T. fragiferum and T. repens,

A comparative study was performed on the three wild Trifolium species and the cultivated one; Trifolium alexandrinum.. The study focused on the micro and macro morphological characters of leaves and seeds, the quality components, in addition to micro-elements. The research aimed to discriminate the genus Trifolium using morphological characteristics and surface properties of the leaflet and the seed using scanning electron microscope and anatomical characteristics to be used as criteria and divisional signs to identify those species in the future.Morever, the aim of this study was to document this wild species in the Egyptian flora and to study the possibility to cultivate them as a fodder plants.

Assessment of the three wild species in terms of forage quality values was compared with Egyptian clover ( $T$. alexandrinum). The study showed that the wild species have a high content of protein, carbohydrate and crude fiber and ash, as well as the content of elements (N.P.K).

The study recommended the possibilities of sowing the wild Trifolium species (alone or intercropping with other forage legumes and grasses) in new broad pasture areas to increase the animal resources in Egypt.
\end{abstract}

Key words: berseem, clover, crude protein, fiber, morphology, SEM ,Trifolium, Trifolium alexandrinum, T. fragiferum, T.repens, T. resupinatum.

\section{INTRODUCTION}

Clovers are considered a very important part of grassland crops among the Legume family. There is some confusion concerning the number of species which the genus Trifolium has been included. Evans, (1976) mentioned that the genus includes more than 250 species of which twenty are of considerable agricultural importance. While, Zohary and Heller, (1984) reported 237 species within this genus. Boulus (1999) indicated that about 240 species of clover are found in Egypt.

Large areas of reclaimed soils are not available to growing with Berseem clover but able to be cultivated alone by some wild Trifolium species or intercropping with other crops such as Trifolium repens, Trifolium fragiferum and Trifolium resupinatum. Berseem Clover (Trifolium alexandrinum L.) is an important winter fodder crop of irrigated areas in Egypt. It is a multi-cut crop which produces nutritious and palatable fodder for the cattle. Fodder yield of berseem is

low in Egypt due to the low yield potential of cultivars being grown by the farmers and limited area in the Delta. Berseem is a high-quality forage characterized by high concentration of nutrients, primarily proteins (15-25\% DM), minerals (1119\%) (Sharma and Murdia 1974). Trifolium repens is a nutritious forage, rich in protein, minerals and soluble carbohydrates. Compared to other temperate forages, it has relatively low levels of fiber and lignin (Thomson, 1984 and INRA, 2007).

Surface sculpturing (by using Scanning Electron Microscope (SEM) technique) may aid in solving problems of identity or relationship concerning taxa at various levels (Werker, 1997).

The seeds of Leguminosae in particular are highly varied in its shape (Kopooshian and Isley, 1966). The great variations in the morphology and the different ornamentations of the seed coat 
support the study of taxa delimitation and may solve and facilitate many taxonomic problems. Vaughan (1968) suggested that the structure of the mature seeds, especially the coat is considered the more taxonomic useful information.

The SEM examinations of seed surface features could be applied in taxonomy and there are many characters (e.g. seed coat) could be used to characterize groups of related species, genera or taxonomic categories up to the sub-family levels. Some characters of the micro-morphology and orientation of epicuticular wax crystalloid are surprisingly of high systematic significance (Barthlott, 1981). Kadry (2002) suggested that the macro and micro morphological characters of seeds (shape, color, size, epidermal cell shape, anticline wall boundaries and the outer periclinal cell walls) were used for species identification.

The objectives of this study were to distinguish the taxonomic relationship between the studied Trifolium species and to compare the nutritive values of these species to increase the animal feeding resources.

\section{MATERIALS AND METHODS}

In this study, four species of the genus Trifolium were examined (Table 1). These species were planted in Medicinal and Aromatic Plants Research Department, Horticultural Research Institute, Agricultural Research Center, Dokki, Giza. The fresh leaves and seeds of each species were used in this study. The detailed surface scan features were examined by using Scanning Electron Microscope (SEM) with different magnifications. Scanning was carried out by JEOL- JSM T 100 Model Scanning Electron Microscope, Central Laboratory National Information and Documentation Center (NIDoC), Dokki, Giza, Egypt.

Micro and macro-morphological characters of leaf and seed surface sculptures were used to explore the relationship between the studied Trifolium species. In addition to, the data obtained from analyzing the chemical components of these species from protein, crude fiber, carbohydrate, and ash percentages, and N.P.K. percentages.

For chemical determinations, sample of $200 \mathrm{~g}$ bulk plants per species were fine powdered and wet digested according to Chapman and Pratt (1961). Nitrogen percentage was determined in plants by wing microkjelhal methods. Phosphorus and potassium percentages were determined by using the procedure described by A. O. A. C. (1990).

The detailed surface scan features were examined by using Scanning Electron Microscope (SEM) with different magnifications. Scanning was carried out by JEOL- JSM T 100 Model Scanning Electron Microscope, Central Laboratory, National Information and Documentation Center (NID $\left.{ }^{\circ} \mathrm{C}\right)$, Dokki, Giza, Egypt. Micro and macro-morphological characters of leaf and seed surface sculptures were used to explore the relationship between the studied Trifolium species. In addition to, the data obtained from analyzing the chemical components of these species from protein, crude fiber, carbohydrate, ash percentages and N.P.K. percentages.

For chemical determinations, a sample of 200 $\mathrm{g}$ bulk plants per species was fine powdered and wet digested according to Chapman and Pratt (1961). Nitrogen percentage was determined in plants by wing microkjelhal methods. Phosphorus and potassium percentages were determined by using the procedure described by A. O. A. C. (1990).

\section{RESULTS AND DISCUSSION}

The species under consideration were studied and the results were gathered according to the following aspects:

Macro and micro-morphological descriptions of leaf (upper and lower surface) (Table 2 and Fig.1), and seed surface (Table 3 and Fig.2) for each species.

1- Macro-morphological descriptions of leaves.

The results revealed that there are three different shapes and sizes of leaflets as follows (Table 2):

i. Oblong to elliptic shape characterized the leaflets of T.alexandrinum. The leaflet length

Table (1): The studied species, growth habit and the collection regions.

\begin{tabular}{|c|l|c|c|}
\hline No. & Species & Habit & Region \\
\hline 1. & Trifolium alexandrinum L. & Cultivated & Field in Giza \\
\hline 2. & Trifolium fragiferum L. & Wild & North Coast (Porg El Arab) \\
\hline 3. & Trifolium repens L. & Wild & North Coast (Porg El Arab) \\
\hline 4. & Trifolium resupinatum L. (=T. suaveolens ) & Wild & North Coast (Porg El Arab) \\
\hline
\end{tabular}


Comparative and taxonomical studies on four trifolium... .......................................................

Table (2): Macro and micro-morphological descriptions of the leaves of the studied species.

\begin{tabular}{|c|c|c|c|c|c|}
\hline \multicolumn{2}{|c|}{$\begin{array}{l}\text { Species } \\
\text { Character }\end{array}$} & T.alexandrinum & T. fragiferum & T. repens & T. resupinatum \\
\hline \multirow{4}{*}{ 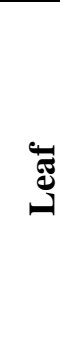 } & Color & Green & $\begin{array}{l}\text { Green with } \\
\text { prominent veins }\end{array}$ & $\begin{array}{l}\text { Green with white } \\
\text { ring }\end{array}$ & Green \\
\hline & Texture & $\begin{array}{l}\text { Appressed hairy or } \\
\text { glabrescent }\end{array}$ & $\begin{array}{l}\text { Glabrous or sparsely } \\
\text { hairy }\end{array}$ & Glabrous & Glabrous \\
\hline & Petiole (cm) & $3-7$ & $8-10$ & $16-18$ & $8-10$ \\
\hline & Arrangement & $\begin{array}{l}\text { The lower alternate\& } \\
\text { upper mostly opposite }\end{array}$ & Alternate & Alternate & Alternate \\
\hline \multirow{6}{*}{ 氖 } & Margin & Serrate & Spinulose-serrate & $\begin{array}{l}\text { Denticulate- } \\
\text { serrulate }\end{array}$ & Serrate - \\
\hline & Shape & Oblong to elliptic & Obovate To Elliptic & $\begin{array}{l}\text { Broadly obovate to } \\
\text { orbicular }\end{array}$ & Obovate to elliptic \\
\hline & Apex & Mucronate & Obtuse or retuse & Obtuse or apiculate & Obtuse or emarginate \\
\hline & Base & Obtuse & Cuneate & Obtuse & Cuneate \\
\hline & Length cm & $1.5-4.6$ & $0.6-1.9$ & $1-2.5$ & $1-2.1$ \\
\hline & Width (cm) & $0.5-1.9$ & $0.4-1.2$ & $0.8-1.7$ & $0.5-1.5$ \\
\hline \multicolumn{2}{|c|}{ Petiolate mm } & Sessile & $2-2.3$ & $1.4-17$ & $3-3.2$ \\
\hline \multirow{5}{*}{ 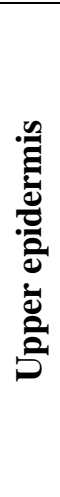 } & Type of stomata & Anomocytic & Anomocytic & $\begin{array}{l}\text { Anisocytic } \\
\text { \&anomocytic }\end{array}$ & Anomocytic \\
\hline & Stomatal leveling & Semi-depressed & $\begin{array}{l}\text { Semi-depressed \& } \\
\text { depressed }\end{array}$ & $\begin{array}{l}\text { Depressed \& } \\
\text { superficial }\end{array}$ & Semi-depressed \\
\hline & Type of trichomes & $\begin{array}{l}\text { Non-glandular } \\
\text { (Hairs) }\end{array}$ & - & - & - \\
\hline & $\begin{array}{l}\text { Trichome } \\
\text { ornamentation }\end{array}$ & $\begin{array}{l}\text { Micropapillate } \\
\text { (Verrucose) }\end{array}$ & - & - & - \\
\hline & Sculpture & Weak reticulate & Colliculate & Ocellate & Areolate - reticulate \\
\hline \multirow{5}{*}{ 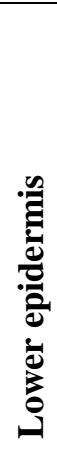 } & Type of stomata & Anomocytic & Anomocytic & Anomocytic & Anomocytic \\
\hline & Stomatal leveling & Superficial & Depressed & Superficial & Superficial \& raised \\
\hline & Type of trichome & $\begin{array}{l}\text { Non-glandular } \\
\text { (Hairs), longer, } \\
\text { Present on all Surface }\end{array}$ & $\begin{array}{l}\text { Non-glandular } \\
\text { (Hairs) Abundance, } \\
\text { only Present on } \\
\text { midrib }\end{array}$ & - & - \\
\hline & $\begin{array}{l}\text { Trichome } \\
\text { ornamentation }\end{array}$ & $\begin{array}{l}\text { Micropapillate } \\
\text { (Verrucose) }\end{array}$ & $\begin{array}{l}\text { Micropapillate } \\
\text { (Verrucose) }\end{array}$ & - & - \\
\hline & Sculpture & Weak reticulate & Reticulate & Rugose & Rugulose \\
\hline
\end{tabular}




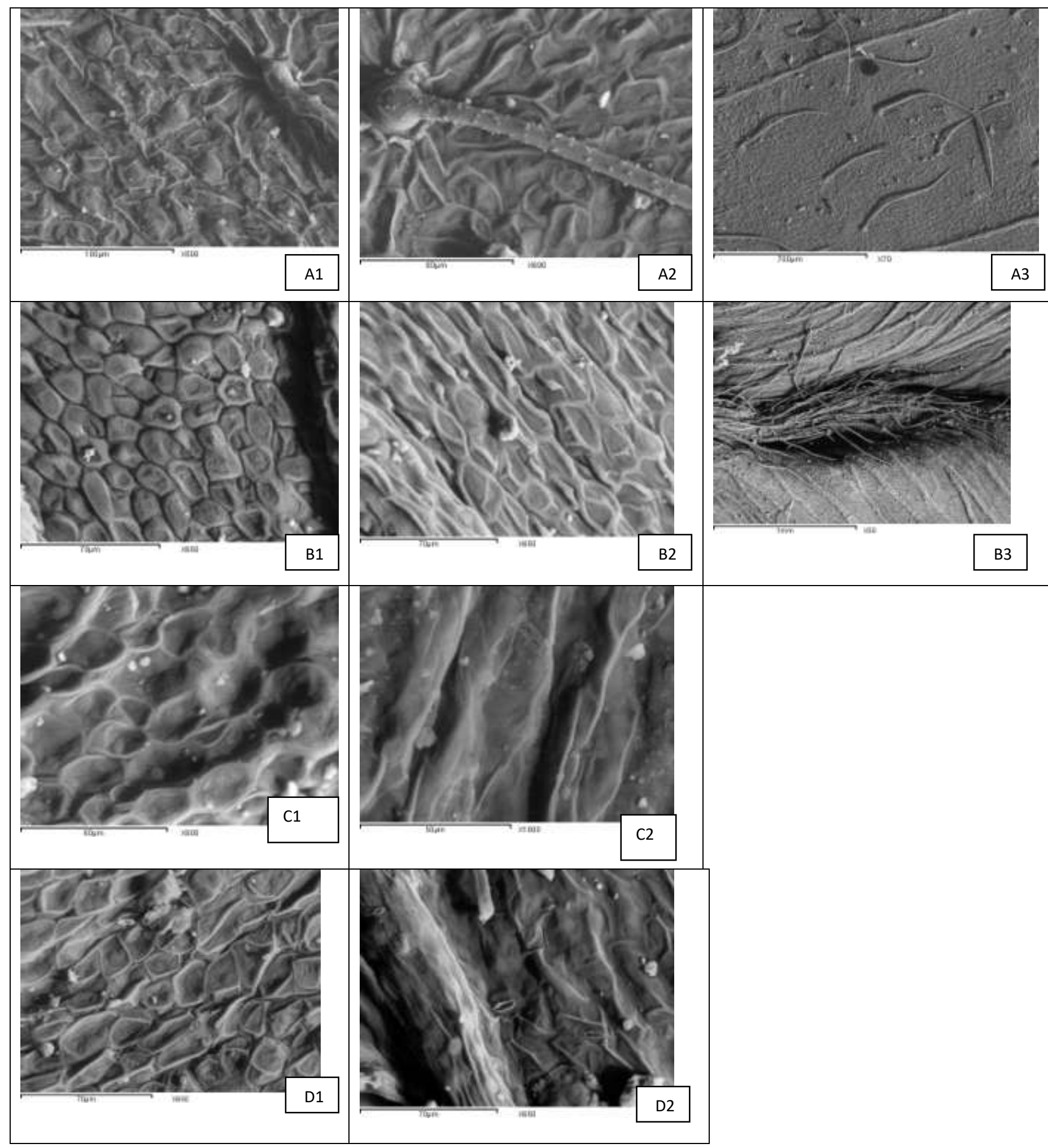

Fig. (1): SEM on leaf epidermis; (1)upper surface,(2) lower surface and trichomes of surface (3)
A) Trifolium alexandrinum
B) $T$. fragiferum
C) T. repens
D) $T$. resupinatu 

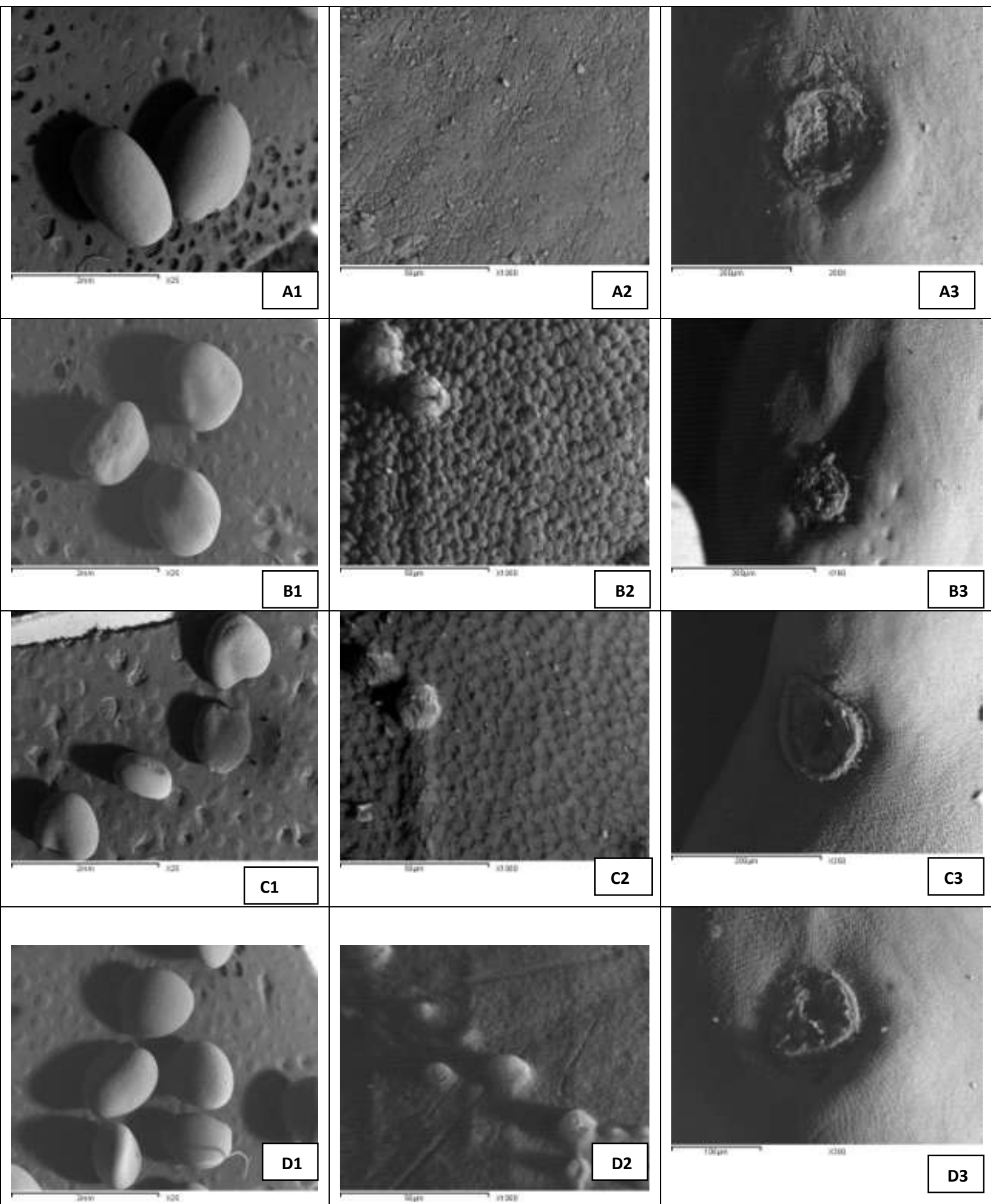

Fig. (2): SEM of seed; shape (1), surface sculpture(2) and hilum (3)

A) Trifolium alexandrinum, B) $T$. repens, C) $T$. fragiferum and D) $T$. resupinatum 
Table (3): Morphological descriptions of the seed of the studied species.

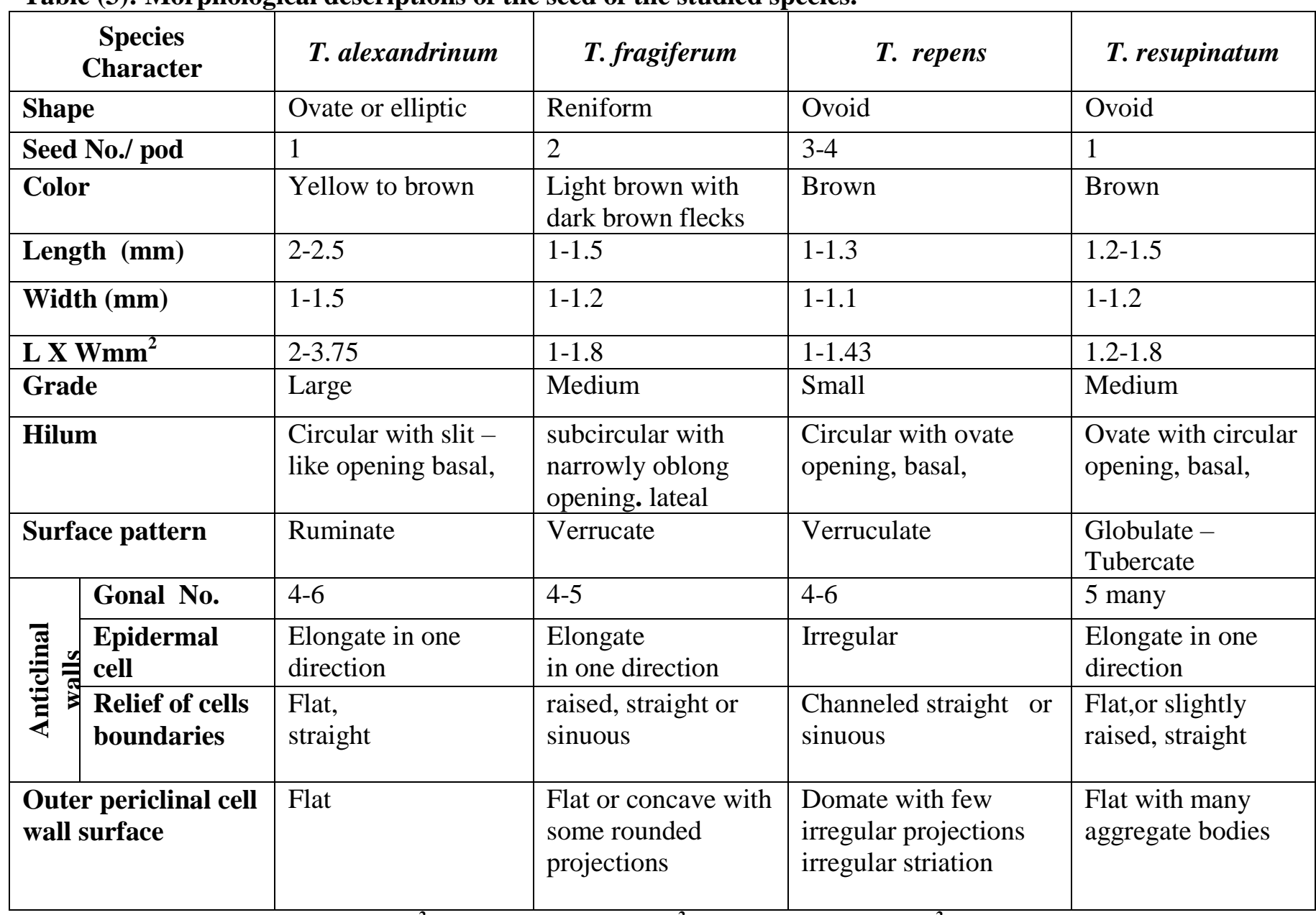

Grade:- Large: equal or more than $2 \mathrm{~mm}^{2}$, Medium:2 $>M>1.6 \mathrm{~mm}^{2}$, Small = less than $1.6 \mathrm{~mm}^{2}$

averaged 1.5-4.6 cm, with mucronate apex and obtuse base.

ii.Obovate to elliptic shape characterized the leaflets of $T$. fragiferum and $T$. resupinatum with leaf length ranged between $0.6-1.9 \mathrm{~cm}$, with cuneate base. Obtuse or retuse apex in $T$. fragiferum and obtuse or emarginate apex in

\section{T. resupinatum.}

iii.Broadly obovate to orbicular shape in $T$. repens, the leaflets length $1-2.5 \mathrm{~cm}$, with obtuse or apiculate apex and cuneate base.

Moreover, all these leaves of studied species were alternate and petiol present. Based on the leaf texture, the studied species split into two categories; glabrous leaves in two species; $T$. repens and $T$. resupinatum and glabrescent or sparsely hairy leaves in the other two species.

\section{2- Micro-morphological descriptions of leaf}

A- Upper epidermis:

There are four sculpture patterns of the upper epidermal surface of leaf of the studied species (Table 2 \& Fig. 1):

- Weak reticulate as in T.alexandrinum. Colliculate as in $T$. fragiferum.
- Ocellate as in T. repens

- Areolate - reticulate as in T. resupinatum.

B- Lower epidermis:

There are three sculpture patterns of the lower epidermal surface of leaf of the studied species (Table 3 \& Fig. 1):

- Reticulate as in T. fragiferum and appearance weak reticulate as in T.alexandrinum.

- Rugose as in T. repens.

- Rugulose as in T. resupinatum.

3-Macro-morphological descriptions of seed (Table 3 \& Fig. 2)

i) Shape and grade

The seeds of the studied species have three varied shape; ovoid in $T$. repens and $T$.

resupinatum, ovate or elliptic in $T$. alexandrinum and reniform in $T$. fragiferum.

The grade exhibits more variability. Mature seeds of all examined species are ranged in size from 1-2.5 x $1-1.5 \mathrm{~mm}$ (Length $\mathrm{x}$ Width). The smallest seeds were those of $T$. repens, while large seeds as in $T$. alexandrinum and remaining two species 
have medium sized seeds.

\section{ii) Color}

In all the studied species, the seed color varies from brown (in $T$. repens and $T$. resupinatum), yellow to brown (in $T$. alexandrinum) to light brown with dark brown flecks (in T. fragiferum).

\section{4- Microrphological descriptions of seed}

i) Sculpture pattern of seed surface

1. Ruminate: as in T. alexandrinum

2. Globulate - Tubercate as in T. resupinatum.

3. Verrucate: as in T. fragiferum.

4. Verruculate: as in $T$. repens.

ii) The anticlinal cell walls

1. Number of gonals

a) Five to Polygonal: as in T. resupinatum.

b) From 4-6: as in T. alexandrinum and $T$. repens.

c) From 4-5: as in T. fragiferum.

2. Relief of cell boundaries

a. Flat: as in T. alexandrinum.

b. Channelled: as in $T$. repens.

c. Raised: as in T. fragiferum

d. Slightly raised:or flat as in, $T$. resupinatum

e. Straight or sinuous: as in $T$. repens.and $T$. fragiferum

f. Straight: as in T.resupinatum and $T$. alexandrinum.

iii) The outer periclinal cell wall surface

a. Flat: as in T. alexandrinum.

b. Flat with many aggregate bodies: as in $T$. resupinatum.

c. Flat or concave with some rounded projections: as in T. fragiferum.

d.Domate with few irregular projections and irregular striation: as in $T$. repens.

iv) The hilum

a. Circular with slit - like opening, basal: as in $T$. alexandrinum and with ovate opening, basal: as in T. repens.

b.Subcircular with narrowly oblong opening. Lateral: as in T. fragiferum.

c. Ovate with circular opening, basal:as in $T$. resupinatum.

\section{Forage quality}

Forage has an important role in ruminant nutrition in terms of providing energy, protein and minerals, as well as fiber for chewing and rumination. In the Mediterranean areas pastures represent the most important forage resource. Clovers are primarily used for pasture, but also for stored feed. Grazing is more convenient and costs less than half the amount of stored feed, which has additional costs associated with hay and silage harvesting and feeding. (Ball et al., 1996).

The high nutritive value of clover allied to its high intake characteristics. Forage crops production is very important for successful animal production (Dabkeviciene et al., 2008). Species had a highly significant effect of quality components, crude protein, carbohydrate, crude fiber and ash percentages (Table 4). In addition, the percentages of macro-elements $(\mathrm{N}, \mathrm{P}$ and $\mathrm{K} \%$ ) in plant tissues were significantly varied according to the species of Trifolium used. The maximum protein and carbohydrate percentages were obtained by T. alexandrinum; 16.56 and $66.82 \%$, respectively. The highest protein percentage was related to high content of $\mathrm{N}(2.64 \%)$ in berseem plant tissues. Santis et al. (2004) suggested the best stage of harvest management per cut, six $^{\text {th }}$ internode elongation, for obtaining relatively high yields of forage with high nutritive value in berseem clover.

T. repens was rich in protein content (13.9\%) and $\mathrm{N}(2.22 \%)$, these results agreed with McGraw

Table (4): Quality of components and NPK elements as a percentage of dry matter of four Trifolium species.

\begin{tabular}{|l|l|l|l|l|l|l|l|}
\hline \multirow{2}{*}{ Species } & \multicolumn{7}{c|}{ As a percentage of dry matter } \\
\cline { 2 - 8 } & CP & Carbohydrate & CF & Ash & N & P & K \\
\hline Trifolium alexandrinum & $16.56^{\mathrm{a}}$ & $66.82^{\mathrm{a}}$ & $29.58^{\mathrm{b}}$ & $11.74^{\mathrm{b}}$ & $2.64^{\mathrm{a}}$ & $0.27^{\mathrm{c}}$ & $3.37^{\mathrm{a}}$ \\
\hline T. repens & $13.93^{\mathrm{b}}$ & $47.89^{\mathrm{c}}$ & $33.74^{\mathrm{a}}$ & $13.78^{\mathrm{a}}$ & $2.22^{\mathrm{b}}$ & $0.27^{\mathrm{c}}$ & $2.29^{\mathrm{c}}$ \\
\hline T. fragiferum & $12.31^{\mathrm{c}}$ & $59.48^{\mathrm{ab}}$ & $28.97^{\mathrm{bc}}$ & $11.26^{\mathrm{b}}$ & $1.96^{\mathrm{c}}$ & $0.32^{\mathrm{b}}$ & $2.97^{\mathrm{b}}$ \\
\hline T. resupinatum & $13.55 \mathrm{~b}^{\mathrm{c}}$ & $62.78^{\mathrm{a}}$ & $27.97^{\mathrm{c}}$ & $13.18^{\mathrm{a}}$ & $2.16^{\mathrm{bc}}$ & $0.45^{\mathrm{a}}$ & $2.94^{\mathrm{b}}$ \\
\hline Mean & 14.09 & 59.24 & 30.06 & 12.50 & 2.45 & 0.33 & 2.89 \\
\hline
\end{tabular}

In each column means followed by similar letters are not significantly different at $5 \%$ level.

$\mathrm{CP}=$ Crude protein, $\mathrm{CF}=$ Crude fiber, $\mathrm{N}=$ Nitrogen, $\mathrm{P}=\mathbf{P h o s p h o r s}$ and $\mathrm{K}=$ Potassium contents in plant tissues. 
et al. (2004). T. repens recorded minimum content of carbohydrates $(47.89 \%)$ with maximum content of crude fiber and ash (33.74 and 13.78\%, respectively) (Table 4). White clover recorded high levels of crude protein, soluble carbohydrates, minerals (especially calcium, phosphorus, magnesium) and low levels of structural carbohydrates and lignin (Ulyatt et al., 1977 and Thomson, 1984). Trifolium repens L. is considered an effective way of improving pasture production and soil $\mathrm{N}$ status in many parts of the world (Gibson and Cope, 1985 and Ledgard and Steele, 1992).

Persian clover (T. resupinatum) recorded high percentage of crude protein, carbohydrate and $\mathrm{P}$ content; $13.5,62.78$ and $0.45 \%$, respectively with the lowest percentage of crude fiber $(27.97 \%)$. T. resupinatum provides a highquality forage (dry matter, crude protein, crude fiber, $\mathrm{P}, \mathrm{K}, \mathrm{Ca}$ and $\mathrm{Mg}$ ) for animals throughout the growing season (Tekeli et al., 2003).

$T$. fragiferum had the lowest $\mathrm{N}$ content $(1.96 \%)$ among all the species under study. Moore et al. (2006) recorded that the percentage of crude protein of $T$. fragiferum ranged from 18 to $23 \%$ but McGraw et al. (2004) concluded that selection for forage quality only; the native legumes did not fare as well as introduced species, having less crude protein and more cell wall fiber. The high percentage of $(\mathrm{K})$ may be pointed to adaptability and tolerant to some ecological stresses. Xingyu Jiang et al. (2010), reported that potassium is a crucial feature for plants under high-salt conditions. Proper harvest timing is important in determining forage quality. The crop should be harvested before blooming period to maintain high forage quality. For $T$. repens, $T$. fragiferum and $T$. resupinatum, harvests in the late vegetative or early bud stage get higher protein content compared with the other harvest periods. The nutritive value of clovers may be influenced by changes in the nutrient concentrations of morphological fractions as a consequence of cutting treatment.

In conclusion, the severe shortage of fodder and the needs to increase the livestock resources especially in the presence of some cultivated species of the genus Trifolium in Egyptian flora encourage plant breeders to study these species. The concentrations of the mineral contents also reflect the mineral status of the soil and the supply of the fertilizer nutrients, and are influenced by the species of the forage crops. The high-quality forage may be obtained from these clovers cut at all the growing stages. According to forage quality components, these clovers can be sown in Egypt as well as berseem and alfalfa climate conditions. There is a possibility to expand growing of the three wide Trifolium species, in extended pastures of the newly reclaimed soils either individually or intercropping with some grasses to improving the forage yield and quality.

\section{REFERENCES}

A.O.A.C (1990). Official Methods Of Analysis. Association Of Analytical Chemists. Washinton, D.C. 1: 73 -74.

Ball, D.M. Hoveland, C.S. and Lacefield G.D. (1996). Southern Forages. $2^{\text {nd }}$ Edition. The Potash \& Phosphate Institute, Atlanta.

Barthlott W. (1981). Epidermal and seed surface characters of plants: Systematic applicability and some evolutionary aspects. Nordic Journal of Botany, Copenhagen (1): 345-355.

Boulus L.(1999).Flora of Egypt.Vol.1 AzollaceaeOxalidaceae. Al-Hadara Publishing. Cairo.Egypt. 419 P.

Chapman H.D. and Pratt F.P. (1961). Ammonium vandate-molybdate method for determination of phosphorus. In: Methods of analysis for soils, plants and water. $1^{\text {st }}$ Ed. California: California University, Agriculture Division, pp: 184-203.

Dabkeviciene G., Paplauskiene V. and Pasakinskiene I. (2008). Assessment of the agronomic utility of interspecific hybrids Trifolium pratense L. x T. diffusum Ehrh. and confirmation of their hybridity with ISSR markers. Journal of Food, Agriculture and Environment 6 (3\&4):187-190.

Evans A. M. (1976). Clovers. In Evolution of Crop Plants. 175-179. N. W. Simmonds (ed). Longman London and New York.

Gibson P.B. and Cope W.A. (1985). White clover. In: Clover Science and Technology. (Ed.): N.L.Taylor. Soil Science Society of America, Madison, WI, USA, pp. 471-490.

Gillet J. B. (1952). The genus Trifolium in southern Arabia and Africa south of the Sahara. Kew Bull. 7:367-404.

INRA (2007). Alimentation des bovins, ovins et caprins. Besoins des animaux - valeurs des aliments.

Kadry N.E. (2002). Biosystematic Studies on Brassicaceae (Cruciferae) in Egypt. Ph. D. Thesis, Wageningen Univ., Holand,. 278 p.

Kopooshian H. and Isley D. (1966). Seeds character relationships in the Leguminosae Proc. Lowa Acad. Sci., 73, 54-67. 
Ledgard S.F. and Steele K.W. (1992). Biological nitrogen fixation in mixed legume/grass pastures. Plant Soil, 141: 137-153.

Mc Graw R.L., Shockley F.W., Thompson J.F. and Roberts C.A. (2004). Native legume species for forage yield, quality and seed production. Native Plants Journal. Vol. 5(2) pp 152-160.

Moore G., Sanford P. and Wiley T. (2006). Perennial pastures for Western Australia ,Department of Agriculture and Food Western Australia, Bulletin 4690, Perth.

Santis G. de, Iannucci A., Dantone D. and Chiaravalle E. (2004). Changes during growth in the nutritive value of components of berseem clover (Trifolium alexandrinum L.) under different cutting treatments in a Mediterranean region. Grass and Forage Science, 59 (4):378-388.

Sharma V. V. and Murdia P. C. (1974). Utilization of berseem hay by ruminants. J. Agr. Sci., 83 (2): 289-293.

Tekeli A.S., Avcıoğlu R. and Ateş E (2003). Changes in some morphological and chemical properties of Persian clover (T. resupinatum L.) in relation to time and above ground biomass. Ankara niversity J. Agr. Sci., 9: 352360.

Thomson D. J. (1984). The nutritive value of white clover. In: Forage legumes (Ed. D.J. Thomson) pp. 78-92. (British Grassland Society: Berkshire, UK)

Ulyatt M.J., Lancaster J.A. and Jones W.T. (1977). The nutritive value of legumes. Proc. New Zeal Grassland Assoc., 38: 107-118.

Vaughan J. G. (1968). Seed anatomy and taxonomy. Proc. Linn. Soc., London. 179: 251255.

Werker E. (1997). Seed Anatomy. Gebrvder Borntraeger, Berlin, Germany. 359 p.

Xingyu Jiang Leidi Eduardo $O$. and Jose M. Pardo. (2010). How do vacuolar NHX exchangers function in plant salt tolerance? J. Plant Signal Behav.; 5(7): 792-795.

Zohary M. and Heller D. (1984). The genus Trifolium. The Israel Academy of Sciences and Humanities. Jerusalem, Israel, pp. 1-15.

$$
\begin{aligned}
& \text { دراسات تصنيفية مقارنة بين أربعة أنواع من البرسيم بمصر } \\
& \text { *نان سلامة عبدالمقصود - زينب محمد عبدالنبى } \\
& \text { قسم بحوث الفلورة وتصنيف النباتات ـ معهد بحوث البساتين و* قسم بحوث العلف ـ معهد بحوث المحاصيل الحقلية }
\end{aligned}
$$

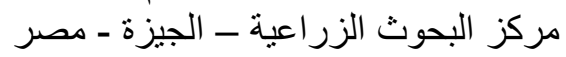

$$
\begin{aligned}
& \text { أجريت هذه الدر اسة على ثلاثة أنواع وجدت بصورة برية في الساحل الثمالي (منطقة برج العرب) و نتنمي لجنس }
\end{aligned}
$$

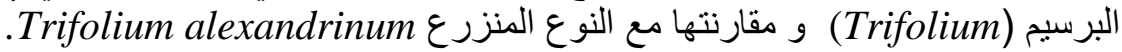

$$
\begin{aligned}
& \text { وكانت الانواع البرية هى: T. repens, T.resupinatum , T. fragiferum }
\end{aligned}
$$

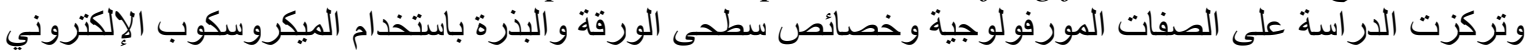

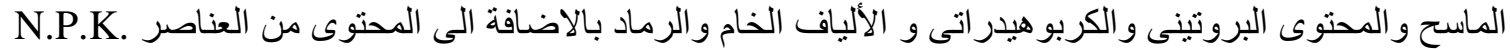

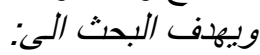

$$
\begin{aligned}
& \text { تمييز انواع جنس Trifolium التي تم در استها باستخدام الصفات المورفولوجية وخصائص المسح السطحى للورقة }
\end{aligned}
$$

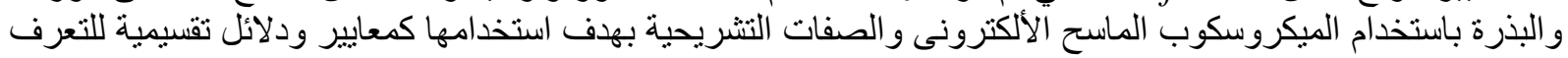

$$
\begin{aligned}
& \text { على تلاك الانو الغئ مستقبلا }
\end{aligned}
$$

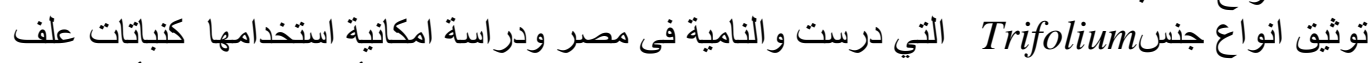

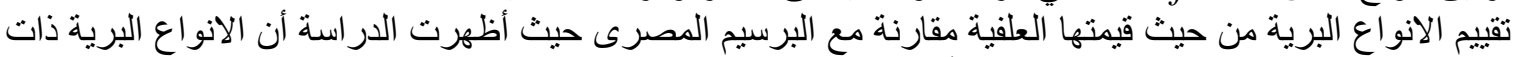

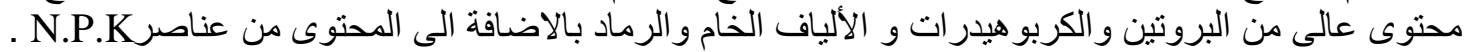

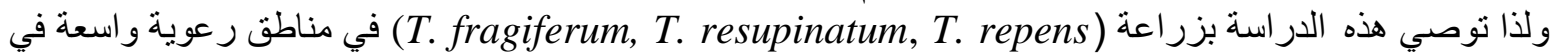

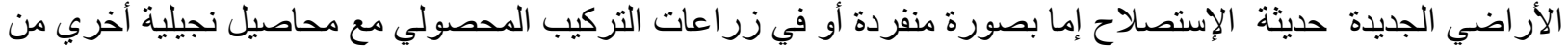

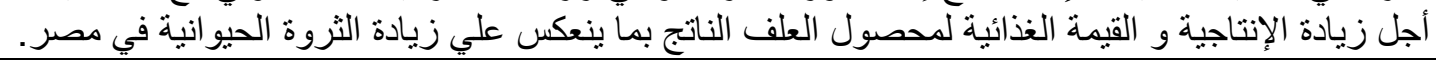

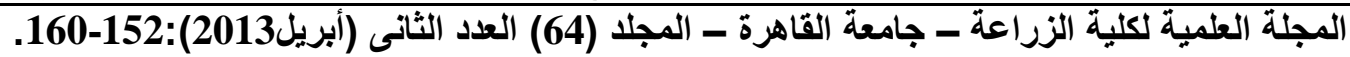

